\title{
Sustainable forest management for Galicia
}

\author{
by E.W. (Ted) Robak1
}

\begin{abstract}
Galicia is the most important forestry region of Spain, but its potential as an engine for economic growth is underdeveloped. Most forests in Galicia are privately owned in small holdings that make it difficult to carry out the sustainable forest management required for forest sector development. This paper outlines a sustainable forest management strategy, and then describes forest management processes and supporting technologies that are seen as necessary for promoting sustainable forest management in a region predominated by small forest ownerships. The paper ends with a brief description of the initial steps that have been taken to implement the strategy.
\end{abstract}

Key words: forest sector planning, small private ownerships, rural and regional economic development, Spain

\section{RÉSUMÉ}

La Galice est la plus importante région forestière de l'Espagne, mais son potentiel en tant que moteur de croissance économique est sous développé. La plupart des forêts de la Galice sont de petites propriétés privées qui rendent difficile la réalisation de l'aménagement forestier durable requis pour le développement du secteur forestier. Cet article illustre la stratégie d’aménagement forestier durable et décrit par la suite les processus d’aménagement forestier et les technologies requises qui sont perçus comme étant nécessaires pour promouvoir l'aménagement forestier durable dans une région où les petites propriétés forestières dominent. Cet article se termine par une brève description des étapes initiales qui ont été entreprises pour implanter cette stratégie.

Mots clés : planification du secteur forestier, petites propriétés privées, développement de léconomie rurale et régionale, Espagne

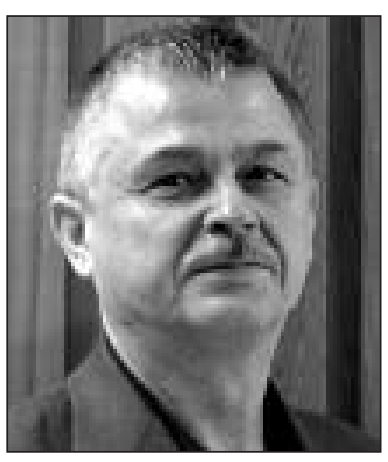

E.W. (Ted) Robak

\section{Introduction}

Galicia is a region of Spain that produces more than $40 \%$ of the national timber supply on $6 \%$ of the country's landbase. Although the most important forestry region of Spain, Galicia's potential as a forest product producer is under-developed since both the amount and unit value of forest production could be greatly increased (Anon. 2001). Given that the Galician agriculture and fishery sectors (traditional bases for economic activity, especially in rural communities) are declining, a healthy forestry sector can be seen as an engine for regional and rural economic development.

One of the primary causes for forest sector under-development is the high degree of private forest ownership in small, scattered holdings. Private forests comprise approximately 97\% of Galician forest lands, with about two thirds of those in holdings of less than 3 ha (often in several non-contiguous parcels). Another $30 \%$ of private forests are owned by communities, but even these average only several hundred hectares.

Such an ownership pattern has made it difficult to promote sustainable forest management and development of the sector. Only a small portion of the forested land is managed in a demonstrably sustainable manner, which does not bode well for the future of industrial forestry given the pressure for certifiably sustainable forest management (SFM) from governments, the general public and the forest product marketplace. This makes it difficult to justify public and private investment in forestry, which in turn impedes investment in forest industry modernization. If the industry is not modernized, the degree of "value-added" processing will remain low, with most raw production sent to other regions for processing.

Given the situation, the government department primarily responsible for forest management for Galicia (Dirección Xeral de Montes e Industrias Forestais, or DXMIF) recognized that it was necessary to change its approach to forest management. In 2001, the author was invited to lead the newly established Observatorio para Xestión Forestal Sostible (OXFS) in formulation of a comprehensive set of new strategies, policies and processes aimed at development of the forest sector based upon principles of sustainable forest management. To a great extent, the strategies and processes that were eventually proposed (as described below) are adapted from the hierarchical forest management and integrated forest management principles and techniques that we teach to our forestry students at the Faculty of Forestry and Environmental Management at the University of New Brunswick.

\section{Development of the Strategy}

In order to develop the strategy, the OXFS began by identifying guiding principles and foundations of SFM based upon international, European Union (EU) and Spanish policies and

\footnotetext{
${ }^{1}$ Professor, Faculty of Forestry and Environmental Management, University of New Brunswick, P.O. Box 44555, Fredericton, New Brunswick E3B 6C2. E-mail: robak@unb.ca
} 
agreements. Then, in order to ensure that the new strategy and its related programs would be consistent with the forestry and environmental policy of the EU, the OXFS reviewed and summarized documentation concerning relevant European Community programs and initiatives.

Further inspiration for development of a new forest strategy was drawn from the concepts of hierarchical forest management and integrated forest management. Hierarchical forest management (HFM) is based upon the tenets of hierarchical production planning as described by such authors as Hax and Candea (1984). Explanations of the hierarchical approach to forest management can be found in various documents, but a paper by Weintraub and Davis (1996) is recommended. Based upon these foundations, a Strategy for Sustainable Forest Management for Galicia was developed and unveiled in the spring of 2002.

\section{The SFM Strategy for Galicia}

The SFM Strategy proposed by the Ministry of the Environment of Galicia represented a new approach to managing the forests of the autonomous region according to principles and norms of sustainable forestry. The eight lines of action proposed to implement the strategy included:

1. Development of the legal framework for sustainable forest management.

2. Establishment of integrated management structures and processes for sustainable forestry.

3. Development of the criteria and indicators of sustainability.

4. Establishment of an accurate and reliable system of forestry information.

5. Promotion of increased research into forest sustainability.

6. Fostering public forestry education to facilitate understanding and participation.

7. Fostering the economic development of the forest sector of Galicia.

8. Promotion of forest certification.

The OXFS proposed a new, integrated forest management process as a critical component of the new strategy. The following sections of this paper focus on the new SFM process and supporting information infrastructure proposed by the OXFS.

\section{The Proposed SFM Process in Galicia}

While many actions and programs are required to implement the new strategy, a key component will involve implementation of a new set of forest management processes. These new processes (Fig. 1) are aimed at integration and coordination of management at regional, district and forest ownership levels while at the same time fostering active participation of forestry stakeholders and Galician society at all levels.

The following are brief descriptions of the three major sub-processes of the proposed new SFM process for Galicia, followed by a description of how they are to interact.

\section{Regional management sub-process}

The first major goal of Regional Management will be to develop a revision to the current Plan Forestal de Galicia (PFG, or Forestry Plan for Galicia) based upon principles of sustainability, input from the public and the forest sector, and the best current forestry knowledge. The revised PFG, developed by regional technical staff within the integrated process described below, will make explicit the long-term forest management goals of the region, the actions required to achieve goals, and terms of the "co-responsibility contract" that define responsibilities of forest sector players with respect to actions. The second goal involves monitoring and control of results and actions to ensure that the specific objectives of SFM for Galicia are being achieved.

\section{District management sub-process}

Forest District Management Plans (FDMPs) are intended to bridge the gap between the PFG and the management plans and actions of Forest Management Units (FMUs). A Forest District in Galicia is a territory of relatively homogenous geographical, socioeconomic, ecological and cultural conditions. According to the most recent draft Plan Forestal de España, this is the level in the management hierarchy where it is most appropriate to accommodate strategic social and economic development objectives defined by local communities and groups and also to consider landscape-level environmental constraints and objectives that require planning across forest ownership boundaries.

\section{Forest management unit sub-process}

Since most individual forests in Galicia are privately owned, the government does not have direct control of the forest management undertaken in them. This is particularly true of the very small ownerships that comprise almost $70 \%$ of Galician forests, where forest management (if there is any) is up to the individual owner. Even in the $30 \%$ of private forests owned by communities and managed by government foresters, community objectives may be at odds with those of the region or district. However, the government can influence the management of private forests: it controls subsidies and has the right to regulate some forest activities such as harvesting. Furthermore, the government is seen as the sole organization capable of implementing a management infrastructure (the planning and control mechanisms and Best Management Practice or BMP Codes) required for regional forest certification, which is seen as the most viable approach to certification given ownership patterns. Until now, in the absence of coherent regional and district plans, the government has been unable to justify using its powers over private forests and, furthermore, making progress on forest certification is seen as problematic. With regional and district forest management guidelines and plans in place, the government will be able to give priority for subsidies and harvest approvals to forest owners who follow the district (and, thereby, regional) plans. As well, the implementation of the planning, monitoring and control systems envisioned in the new SFM process will facilitate certification of even small forest ownerships, as long as they are managed in a way that conforms to the local FDMP and BMPs.

\section{Management integration processes}

The application of hierarchical forest management requires that problems be decomposed and the various elements handled at the appropriate level of the management hierarchy. However, since it is usually impossible to solve all parts of the problem simultaneously, it is necessary to use an iterative approach to planning and control. This means that, although higher levels of the hierarchy give direction to (or constrain) 


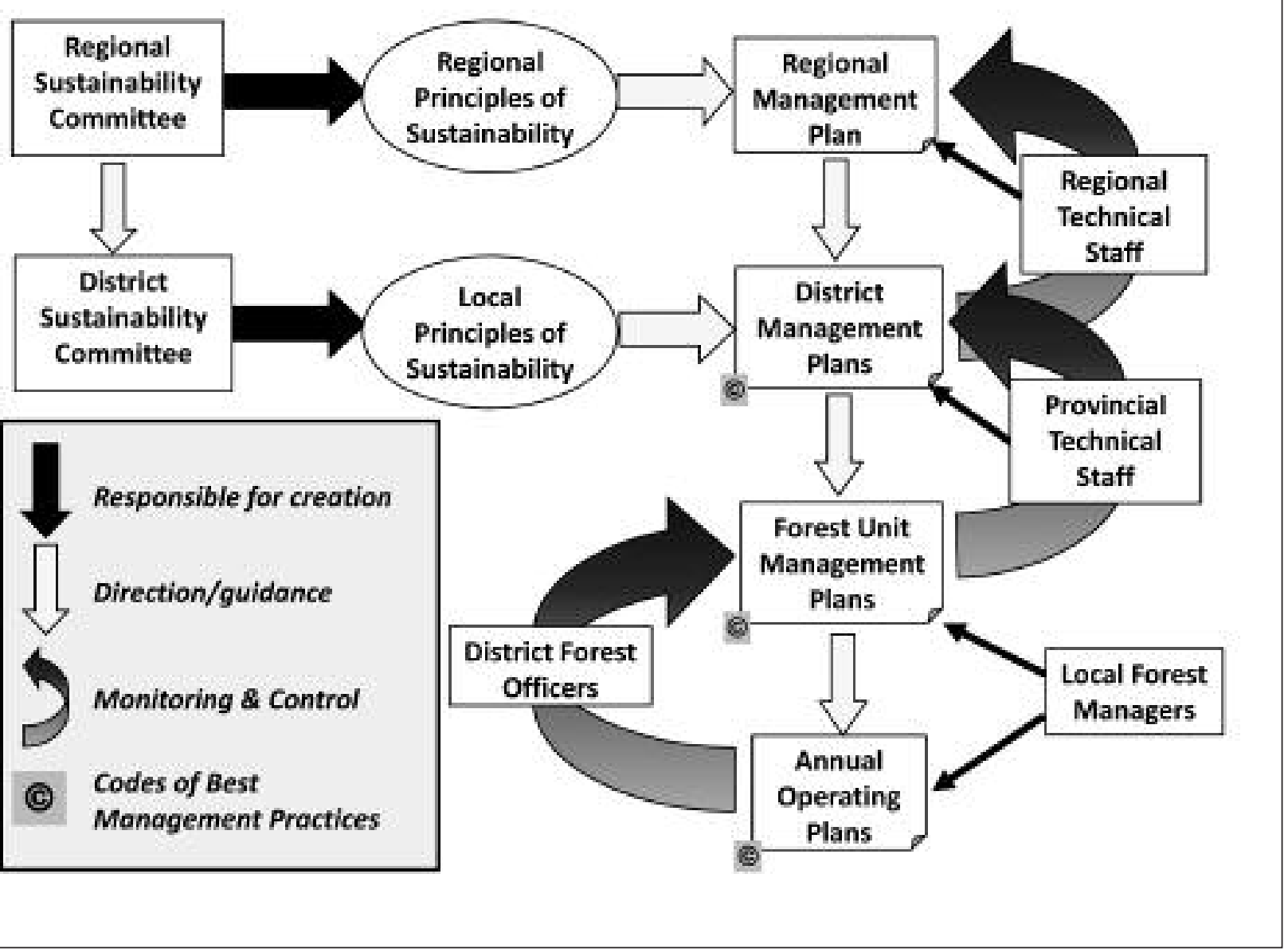

Fig. 1. Proposed sustainable forest management process for Galicia.

the lower-level management processes, the lower-level processes should provide feedback to the upper levels so that the plans and decisions at higher levels can be refined and improved. Depending upon the complexity and importance of the problem and the time involved and available, several iterations of this process might occur. In the case of the proposed SFM process for Galicia, the main steps of this iterative approach are expected to be as follows:

1. A draft regional plan will be developed by the regional DXMIF technical staff based upon the declaration of principles from the Regional Sustainability Committee, the current state of the forest, knowledge of forest processes, forecasts of forest products markets and other economic data and forecasts. The draft plan will be generally aspatial and long-term, and will require use of special modelling and forecasting tools.

2. This rough first version of the regional plan will be passed down to districts as guidelines and constraints to Forest District planners. It might indicate, for example, district targets related to reforestation, wildlife habitat, timber production, production of non-timber products over a long time horizon.

3. Initial district objectives and constraints will be defined by the District Committees by way of the Declaration of Local Objectives of Sustainable Forestry in cooperation with provincial and Forest District staff who will provide data, information and guidance to ensure that regional guidelines are properly interpreted and that objectives are realistic given the geophysical and cultural characteristics of the district.

4. The provincial technical staff will develop a long-term, strategic, generally aspatial, multi-objective forest management plan for each district as if all of these forests were being managed by the forest service. Again, forecasting and modelling tools will be required that use knowledge and information concerning forests and economic and social factors in the district. These district plans must also take into account the expected probabilities of success in convincing forest owners to follow the district plan. The goal is to produce a district plan describing actions to be undertaken, results expected and resources (and policies) required for implementation. The district plan will also describe the actions and investments promised by other "co-responsible" parties involved in implementation, such as a community that promises to find investment for a value-added plant to process a certain kind of product that is or will be available from the forest.

5. Once a district plan that is acceptable to the entire district (and provincial staff) has been developed, it will be passed back up to the regional staff for evaluation and possible 
approval. The evaluation process will involve ensuring that the guidelines have been followed, the regional objectives have been met, and the resources (and policies) required by the district are appropriate. For example, although each individual district plan could be reasonable, the budget requirements of all the districts together might not be able to be satisfied. It will be up to the regional staff to use their own information and models, along with information from the districts, to produce a rational distribution of resources. Thus, budget rationing may require that some district plans be revised, taking into account the budgetary constraints for that district. It is also certain that information from district plans will prompt revisions of the regional plan.

6. Once final versions of the district plans have been completed and approved, these can be used to produce a final version of the Plan Forestal de Galicia since most of the actions, results and resource requirements necessary to carry out the regional plan are in the district plans.

7. During the period of implementation of the regional and district plans, it will be necessary to monitor the actions and results in individual FMUs to ensure that the plans are being followed and that the results are as expected. Besides acting as a control mechanism, the monitoring processes will help to provide the data and information necessary for subsequent iterations of the planning cycle. Such a monitoring system, if properly designed, could also support regional forest certification for any forest owner who follows the district plans (and BMPs).

Implementation of the proposed SFM process for Galicia will require much greater availability of reliable data and information for planning, and much better monitoring systems than now exist. The following section of this paper gives a brief description of the Information Technology infrastructure envisaged for the planning and control functions of the process.

\section{Data and Information Infrastructure}

A significant investment in information systems and data structures is required to support the new SFM strategy and process. These systems and structures include:

- the Network of Environmental Information (RIMAX, in Galician), for basic spatial and attribute forestry data to be used by all levels of management and, eventually, the public;

- integrated forest management tools used to ensure that plans at all levels of the management hierarchy are consistent, that actions and outcomes are monitored and controlled, and that decisions are justified and documented;
- monitoring and control systems to compare outcomes to criteria and indicators of sustainability, to support regional forest certification initiatives, and to enable reporting of results to the public and to national, EU and international agencies.

\section{Current Status}

As can be imagined, the implementation of such a great change is not without its problems. Perhaps the greatest obstacles to be overcome are the lack of knowledge concerning such new management processes on the part of key players, the lack of information concerning the forests and other key factors, and the great difficulty in coordinating the design, development and implementation of so many interrelated programs and actions. Up to October 2007, the following initiatives had been undertaken:

- Education sessions related to SFM, forest certification and information systems for forest management were provided to forest service personnel;

- Presentations of the proposed SFM Strategy for Galicia were made to a large percentage of the forest sector;

- RIMAX (http://inspire.xunta.es/), which provides web access to forestry spatial and attribute data to forest service staff, is now in place;

- Preliminary designs for the integrated forest management system and monitoring and control systems were developed;

- New instructions for forest management planning were instituted, which are more consistent with the principles of SFM as outlined in the Strategy;

- New guidelines for the submission of standardized forest management plan data (consistent with criteria and indicators of sustainability in the EU) were developed and put in place.

Other initiatives that are expected to be initiated in the near future include establishment of district-level planning pilot projects, formation of district committees and establishment of the Galician Council for Sustainable Forestry.

\section{References}

Anon. 2001. O Monte Galego En Cifras. Dirección Xeral de Montes e Industrias Forestais, Consellería de Medio Ambiente, Xunta de Galicia. Hax, A.C. and D. Candea. 1984. Production and inventory management. Prentice-Hall, Inc., Englewood Cliffs, NJ. 513 p.

Weintraub, A. and L.S. Davis. 1996. Hierarchical planning in forest resource management: Defining the dimensions of the subject area. In D. Martell, L.S. Davis and A. Weintraub (eds.). Hierarchical Approaches to Forest Management in Public and Private Organizations. pp. 2-14. Canadian Forest Service, Petawawa National Forestry Institute. Information Report PI-X-124. 